\title{
The Effect of the Addition of Noni Juice to Seluang Fish Kerupuk on Characteristics and Acceptability
}

\author{
$1^{\text {st }}$ Ahmad Sadiq \\ Politechnic Nutrition \\ Department Ministry of health \\ Palembang, Indonesia \\ sadiq@poltekkespalembang.ac.id
}

\author{
$2^{\text {nd }}$ Messy Novita Utami \\ Politechnic Nutrition \\ Department Ministry of health \\ Palembang, Indonesia \\ messynu@gmail.com
}

\author{
$3^{\text {rd }}$ Bina Farihani \\ Politechnic Nutrition \\ Department Ministry ofhealth \\ Palembang, Indonesia \\ binafarihani29@gmail.com
}

\author{
$4^{\text {th }}$ Siti Ainun Karmilah Putri \\ Politechnic Nutrition \\ Department Ministry of health \\ Palembang, Indonesia \\ nyayusakp@gmail.com
}

\author{
$5^{\text {th }}$ Tiara Serlyta \\ Politechnic Nutrition \\ Department Ministry of health \\ Palembang, Indonesia \\ tiaraserlyta2017@gmail.com
}

Corresponding author: sadiq@ poltekkespalembang.ac.id

\begin{abstract}
Kerupuk is one of the typical Palembang foods in the form of snacks as a variation in side dishes or as a complement to the main meal. This research is expected to be able to make a new output on the typical Palembang Kerupuk by using seluang fish as a base material and adding nutrient-rich noni fruit. With the existence of noni seluang fish Kerupuk, it is hoped that it can be used as a healthy snack alternative for children and adolescents. This research is an experimental study using a non-factorial completely randomized design (CRD) with 4 treatments and 3 replications. Data collection methods used in this study include organoleptic tests and chemical tests. From the results of the study, it was concluded that the best Kerupuk formula according to the assessment of the organoleptic test was Kerupuk P4 (200 grams of sago flour, 100 grams of fish, $125 \mathrm{ml}$ of noni juice). The results of the proximate analysis of $P 4$ (water content of $6.09 \%$; ash content of $3.28 \%$; fat content of $18.34 \%$; protein content of $5.44 \%$ and carbohydrate content of $66.85 \%$ ).
\end{abstract}

Keywords—Kerupuk, seluang fish, noni, nutrients.

\section{INTRODUCTION}

Kerupuk from various regions in Indonesia usually have distinctive characteristics whose characteristics are determined by the use of the main ingredients in the form of fish and shrimp so that they give a distinctive taste and aroma. Fish Kerupuk is a dry food product made from starch and fish meat with the addition of other ingredients and permitted food additives (BSN (1999)). According to data from the National Socio-Economic Survey (Susenas), the population of urban areas is larger than the population of countryside (rural). In other words, it can be said that the expenditure for Kerupuk consumption in urban areas is greater than the expenditure for Kerupuk consumption in countryside. This is evident from kerupuk consumption data of the Indonesian people based on the regions shown in Table 1.1.

Table I. Average Per Capita Consumption and Expenditure of Kerupuk by

\begin{tabular}{lll} 
Region & Total (ons) & Rupiah (Rp) \\
\hline Urban & 0,193 & 154 \\
Countryside & 0,147 & 99 \\
Urban + Countryside & 0,166 & 122 \\
\hline Resource: Susenas, Pengeluaran & untuk Konsumsi Penduduk Indonesia, 2003
\end{tabular}

Resource: Susenas, Pengeluaran untuk Konsumsi Penduduk Indonesia, 2003 
Seluang fish (Rasbora argyrotaenia) is a fish species found in the Musi river, South Sumatra. This fish is popular in Sumatra to Kalimantan and several waters in Indonesia. Aryani (2015) obtained Rasbora argyrotaenia in the Kampar Kanan river, Riau province. Yustina (2001) Rasbora argyrotaenia is also found in the Rengau river, Riau province. Lisna (2013) has collected Rasbora argyrotaenia from the Kumpeh Muaro Jambi river. Rosadi (2014) also found space in the Barito river, South Kalimantan. Seluang fish are also known to live in the Rungan river of Central Kalimantan,[1]. Calcium is a micronutrient needed by the body and the most abundant mineral in the body, namely $1.5-2 \%$ of adult body weight or approximately $1 \mathrm{~kg}$ [2].Serum calcium is one percent of total body calcium, found in extracellular fluids and soft tissues. Serum calcium consists of ionic components (50\%), which are coated with protein $(40 \%)$, especially albumin, and a small portion (8-10\%) consisting of organic and inorganic acids such as citrate, lactate, bicarbonate and sulfate [3].

Almost all of the calcium in the body is in the bones which play a role in the structure and strength of bones and teeth[2]. The main source of calcium in food is in milk and its processed products, such as cheese or yogurt. Sources of calcium other than milk are also important to meet calcium needs, either from animal or vegetable origin. Sources of calcium derived from animal sources, such as sardines, fish eaten with bones, including dried fish are good sources of calcium. Vegetable sources of calcium, such as cereals, nuts and beans, tofu and tempeh, and green vegetables are good sources of calcium too, but these foods contain many substances that inhibit the absorption of calcium such as fiber, phytate and oxalate. [2] Fish and seafood contain more calcium than beef or chicken [2]. Adolescence is a good time to maximize bone density because at this time there is more bone mass formation than resorption, which is about $45 \%$ or more [4]. Calcium storage is also four times more in adolescence than during childhood and adulthood [5]. Finn (1998) states that, about $91 \%$ of adult bone volume is formed at the age of 17. Calcium consumption ..., Endang Mulyani, FKM UI, 200916 [6]. In adolescence the absorption of calcium from food reaches $75 \%$. Then it decreases to $20-40 \%$ once you reach adulthood.

Therefore, it is very important to optimize calcium consumption in adolescence. The best source of calcium is in food. Calcium food sources must be consumed every day to meet the daily calcium needs. Even so, teenagers in the world generally lack calcium intake. Research Storey (2004) in America the average adolescent calcium consumption is only $704-1022 \mathrm{mg} /$ day from the recommended $1300 \mathrm{mg} /$ day [7]. In several studies on calcium intake conducted on several ethnicities in the world, Asian ethnicity has always been the lowest when compared to other ethnicities. Boot, et al (1997) stated that the calcium consumption of Asian ethnic groups is lower, namely $759 \mathrm{mg} /$ day than Caucasians, which is $1180 \mathrm{mg} /$ day. Novotny et al (2003) also reported the same thing. Asian calcium intake is the lowest at $868 \mathrm{mg} /$ day when compared to white people (1180 mg/ day) and Hispanics (896 mg / day).

Likewise, with calcium intake in Indonesia. Adequacy of calcium in adolescents in Indonesia is $1000 \mathrm{mg} /$ day [8]. However, what happens is the average consumption of calcium is only $240 \mathrm{mg} /$ day (www.pdpersi.co.id, 2006). Research by Fikawati and Syafiq (2003) shows that the average consumption of calcium in adolescents at Bogor City Public High School is $526.9 \mathrm{mg}$ per day. This average figure seems high because there are outliers, namely those who take calcium supplements, if it is calculated without outliers the figure is much lower, namely $394.7 \mathrm{mg}$ per day. Research by Fikawati, Syafiq, Puspasari (2005) on adolescents in Bandung also states that the average calcium adequacy is still lacking, namely $517 \mathrm{mg} /$ day. Noni fruit has been known for thousands of years by Asian and European nations. So that the noni has various names. In western countries, noni is known as Quin of Heart, in Australia it is known as Cheese Fruit. The Malaysian nation calls noni by the name of the Big Noni or Male Noni. In Thailand the term for noni is Yo Ban.

Whereas in Indonesia itself, noni has various names, including Pace, Betis, Kemudu, Noni, Cengkudu, and so on [9]. Noni is usually only used as traditional medicine. People rarely consume noni as their daily food. Noni fruit has a lot of benefits, especially the content of lysine, xeronin, and scopoletin. Where lysine and xeronin can activate the calcium and protein content contained in whole fish so that their absorption is more optimal (Djauhariya, et al., 2006). Then scopoletin has anti- microbial and anti-fungal properties so that it can reduce the fishy odor in fish [10].

\section{METHODS}

This research is an experimental study using a nonfactorial completely randomized design (CRD) with 4 treatments and 3 replications. The formula used is:

1. $\mathrm{P} 1=100$ grams of Seluang fish +200 grams of tapioca flour

+0 gram of Noni Juice

2. $\mathrm{P} 2=100$ grams of Seluang fish +200 grams of tapioca flour

+50 grams of Noni Juice 
3. $\mathrm{P} 3=100$ grams of Seluang fish +200 grams of tapioca flour +100 gram of Noni Juice

4. $\quad \mathrm{P} 4=100$ grams of Seluang fish +200 grams of tapioca flour

+125 grams of Noni Juice

Data collection methods used in this study include organoleptic tests and chemical tests.

\section{A. Chemical Test}

Chemical tests were carried out in the chemistry laboratory in the department of nutrition at the Health Polytechnic of the Ministry of Health, Palembang. The chemical test aims to determine the nutritional value including: levels of carbohydrates, protein, fat, calcium in Kerupuk with substitutes for fish and noni.

\section{B. Organoleptic test}

Organoleptic test or preference test is a test of the material being tested. The organoleptic test is used for testing where the panelist expresses happy or unhappy responses to the properties of the material being tested. The panelists used were 30 semi-trained panelists.

Data analysis in this research is by using computerized correlation.

\section{RESULT}

\section{A. General Description}

The campus of the Department of Nutrition, Polytechnic of the Ministry of Health in Palembang as a place for manufacture and for conducting organoleptic tests on the research "The Effect of Addition of Noni Juice to Seluang Fish Kerupuk on Characteristics and Acceptability" with 30 college students from the Department of Nutrition, Polytechnic of the Ministry of Health Palembang which was implemented on July 29, 2019.

\section{B. Organoleptic Test Results of taste of Seluang Fish Kerupuk and Noni Juice}

The results of the analysis of the organoleptic test on the taste of fish kerupuk and noni juice can be seen in table 2
Table 2. Taste Criteria for Seluang Fish Kerupuk and Noni Juice

\begin{tabular}{lcccccccc}
\hline \multirow{2}{*}{ Taste Criteria } & \multicolumn{1}{c}{$\mathrm{P} 1$} & \multicolumn{1}{c}{$\mathrm{P} 2$} & \multicolumn{2}{c}{$\mathrm{P} 3$} & \multicolumn{2}{c}{$\mathrm{P} 4$} \\
\cline { 2 - 9 } & $\mathrm{n}$ & $\%$ & $\mathrm{n}$ & $\%$ & $\mathrm{n}$ & $\%$ & $\mathrm{n}$ & $\%$ \\
\hline Like Extremly & 1 & 3.3 & 0 & 0 & 1 & 3.3 & 4 & 13.3 \\
\hline $\begin{array}{l}\text { Like very } \\
\text { much }\end{array}$ & 6 & 20.0 & 9 & 30.0 & 7 & 23.3 & 7 & 23.3 \\
\hline $\begin{array}{l}\text { Like } \\
\text { moderately }\end{array}$ & 9 & 30.0 & 12 & 40.0 & 10 & 33.3 & 17 & 56.7 \\
\hline Like slightly & 7 & 23.3 & 7 & 23.3 & 5 & 16.7 & 1 & 3.3 \\
\hline $\begin{array}{l}\text { Neither like } \\
\text { Nor Dislike }\end{array}$ & 5 & 16.7 & 0 & 0 & 3 & 10.0 & 1 & 3.3 \\
\hline $\begin{array}{l}\text { Dislike } \\
\text { slightly }\end{array}$ & 2 & 6.7 & 2 & 6.7 & 3 & 10.0 & 0 & 0 \\
\hline $\begin{array}{l}\text { Dislike } \\
\text { moderately }\end{array}$ & 0 & 0 & 0 & 0 & 1 & 3.3 & 0 & 0 \\
\hline $\begin{array}{l}\text { Dislike } \\
\text { very much }\end{array}$ & 0 & 0 & 0 & 0 & 0 & 0 & 0 & 0 \\
\hline $\begin{array}{l}\text { Dislike } \\
\text { extremely }\end{array}$ & 0 & 0 & 0 & 0 & 0 & 0 & 0 & 0 \\
\hline TOTAL & 30 & 100 & 30 & 100 & 30 & 100 & 30 & 100 \\
\hline
\end{tabular}

From the results of table 2 it is found that the taste of seluang fish kerupuk and noni juice that is most preferred by the panelists is $\mathrm{P} 4$ with a composition of 200 grams of sago starch, 100 grams of fish and $125 \mathrm{ml}$ of noni juice.

\section{Organoleptic Test Results of aroma of Seluang} Fish Kerupuk and Noni Juice

Organoleptic test analysis of the aroma of fish kerupuk and noni juice can be seen in table 3

Table 3. Aroma Criteria for Seluang Fish Kerupuk and Noni Juice

\begin{tabular}{lcccccccc}
\multicolumn{1}{c}{ Noni Juice } \\
\hline $\begin{array}{l}\text { Aroma } \\
\text { Criteria }\end{array}$ & $\mathrm{N}$ & $\%$ & $\mathrm{n}$ & $\%$ & $\mathrm{~N}$ & $\%$ & $\mathrm{n}$ & $\%$ \\
\hline $\begin{array}{l}\text { Like } \\
\text { Extremly }\end{array}$ & 0 & 0 & 2 & 6.7 & 1 & 3.3 & 1 & 3.3 \\
\hline $\begin{array}{l}\text { Like very } \\
\text { much }\end{array}$ & 9 & 30.0 & 7 & 23.3 & 9 & 30.0 & 7 & 23.3 \\
\hline $\begin{array}{l}\text { Like } \\
\text { moderately }\end{array}$ & 10 & 33.3 & 16 & 53.3 & 7 & 23.3 & 8 & 26.7 \\
\hline $\begin{array}{l}\text { Like } \\
\text { slightly }\end{array}$ & 4 & 13.3 & 1 & 3.3 & 5 & 16.7 & 2 & 6.7 \\
\hline $\begin{array}{l}\text { Neither like } \\
\text { nor Dislike }\end{array}$ & 6 & 20.0 & 4 & 13.3 & 6 & 20.0 & 10 & 33.3 \\
\hline $\begin{array}{l}\text { Dislike } \\
\text { slightly }\end{array}$ & 0 & 0 & 0 & 0 & 2 & 6.7 & 1 & 3.3 \\
\hline \hline $\begin{array}{l}\text { Dislike } \\
\text { moderately }\end{array}$ & 1 & 3.3 & 0 & 0 & 0 & 0 & 1 & 3.3 \\
\hline $\begin{array}{l}\text { Dislike } \\
\text { very much }\end{array}$ & 0 & 0 & 0 & 0 & 0 & 0 & 0 & 0 \\
\hline $\begin{array}{l}\text { Dislike } \\
\text { extremely }\end{array}$ & 0 & 0 & 0 & 0 & 0 & 0 & 0 & 0 \\
\hline \hline \begin{tabular}{l} 
TOTAL \\
\hline$y y y y y y y y$
\end{tabular} & 30 & 100 & 30 & 100 & 30 & 100 & 30 & 100 \\
\hline
\end{tabular}


From the results of table 3 , it is found that the aroma of fish kerupuk and noni juice that is most preferred by the panelists is $\mathrm{P} 2$ with a composition of 200 grams of sago starch, 100 grams of fish and $50 \mathrm{ml}$ of noni juice.

\section{Organoleptic Test Results of Color of Seluang Fish Kerupuk and Noni Juice}

Organoleptic test analysis of Seluang fish kerupuk and noni juice can be seen in table 4

\section{Table 4. Color Criteria for Seluang Fish Kerupuk and Noni Juice}

\begin{tabular}{lcccccccc}
\hline Color Criteria & \multicolumn{2}{c}{$\mathrm{P} 1$} & \multicolumn{2}{c}{$\mathrm{P} 2$} & \multicolumn{2}{c}{$\mathrm{P} 3$} & \multicolumn{3}{c}{$\mathrm{P} 4$} \\
\cline { 2 - 8 } & $\mathrm{n}$ & $\%$ & $\mathrm{n}$ & $\%$ & $\mathrm{n}$ & $\%$ & $\mathrm{n}$ & $\%$ \\
\hline Like Extremly & 0 & 0 & 0 & 0 & 0 & 0 & 0 & 0 \\
\hline $\begin{array}{l}\text { Like very } \\
\text { much }\end{array}$ & 5 & 16.7 & 6 & 20.0 & 5 & 16.7 & 6 & 20.0 \\
\hline Like moderately & 12 & 40.0 & 12 & 36.7 & 12 & 40.0 & 15 & 50.0 \\
\hline $\begin{array}{l}\text { Like } \\
\text { slightly }\end{array}$ & 6 & 20.0 & 5 & 16.7 & 5 & 16.7 & 6 & 20.0 \\
\hline $\begin{array}{l}\text { Neither like nor } \\
\text { Dislike }\end{array}$ & 6 & 20.0 & 3 & 10.0 & 5 & 16.7 & 1 & 3.3 \\
\hline $\begin{array}{l}\text { Dislike } \\
\text { slightly }\end{array}$ & 1 & 3.3 & 3 & 10.0 & 1 & 3.3 & 1 & 3.3 \\
\hline $\begin{array}{l}\text { Dislike } \\
\text { moderately }\end{array}$ & 0 & 0 & 1 & 0 & 1 & 3.3 & 1 & 3.3 \\
\hline $\begin{array}{l}\text { Dislike } \\
\text { very much }\end{array}$ & 0 & 0 & 0 & 0 & 1 & 3.3 & 0 & 0 \\
\hline $\begin{array}{l}\text { Dislike } \\
\text { extremely }\end{array}$ & 0 & 0 & 0 & 0 & 0 & 0 & 0 & 0 \\
\hline \begin{tabular}{l} 
TOTAL \\
\hline
\end{tabular} & 30 & 100 & 30 & 100 & 30 & 100 & 30 & 100 \\
\hline
\end{tabular}

From the results of table 4, it is found that the Color of seluang fish kerupuk and noni juice that is most preferred by the panelists is $\mathrm{P} 4$ with a composition of 200 grams of sago starch, 100 grams of fish and 125 $\mathrm{ml}$ of noni juice.

E. Organoleptic test results of the texture of Seluang Fish Kerupuk and Noni Juice

The results of the analysis of the organoleptic test on the texture of Seluang fish kerupuk and noni juice can be seen in table 5 .
Table 5. Texture Criteria for Seluang Fish Kerupuk and Noni Juice

\begin{tabular}{lllllllll}
\hline $\begin{array}{l}\text { Texture } \\
\text { Criteria }\end{array}$ & \multicolumn{2}{c}{ P1 } & \multicolumn{2}{c}{ P2 } & \multicolumn{2}{c}{ P3 } & P4 \\
\cline { 2 - 9 } & $\mathrm{n}$ & $\%$ & $\mathrm{n}$ & $\%$ & $\mathrm{n}$ & $\%$ & $\mathrm{n}$ & $\%$ \\
\hline $\begin{array}{l}\text { Like } \\
\text { Extremly }\end{array}$ & 1 & 3.3 & 0 & 0 & 0 & 0 & 2 & 6.7 \\
\hline $\begin{array}{l}\text { Like very } \\
\text { much }\end{array}$ & 2 & 6.7 & 6 & 20.0 & 7 & 23.3 & 10 & 40.0 \\
\hline $\begin{array}{l}\text { Like } \\
\text { moderately }\end{array}$ & 5 & 16.7 & 7 & 23.3 & 4 & 13.3 & 5 & 16.7 \\
\hline $\begin{array}{l}\text { Like slightly } \\
\text { Neither like }\end{array}$ & 11 & 36.7 & 7 & 23.3 & 9 & 30.0 & 5 & 16.7 \\
nor Dislike & 3 & 10.0 & 3 & 10.0 & 3 & 10.0 & 4 & 13.3 \\
\hline $\begin{array}{l}\text { Dislike } \\
\text { slightly }\end{array}$ & 1 & 3.3 & 4 & 13.3 & 2 & 6.7 & 3 & 10.0 \\
\hline $\begin{array}{l}\text { Dislike } \\
\text { moderately }\end{array}$ & 6 & 20.0 & 2 & 6.7 & 4 & 13.3 & 1 & 3.3 \\
\hline $\begin{array}{l}\text { Dislike very } \\
\text { much }\end{array}$ & 0 & 0 & 1 & 3.3 & 1 & 3.3 & 0 & 0 \\
\hline $\begin{array}{l}\text { Dislike } \\
\text { extremely }\end{array}$ & 1 & 3.3 & 0 & 0 & 0 & 0 & 0 & 0 \\
\hline TOTAL & 30 & 100 & 30 & 100 & 30 & 100 & 30 & 100 \\
\hline & & & & & & & & \\
\hline
\end{tabular}

From the results of table 5, it is found that the texture of seluang fish kerupuk and noni juice that is most preferred by the panelists is $\mathrm{P} 4$ with a composition of 200 grams of sago starch, 100 grams of fish and 125 $\mathrm{ml}$ of noni juice.

\section{F. Laboratory Test Results for Seluang Fish Kerupuk andNoni Juice}

Table 6. Proximate Test Results for Seluang Fish Kerupuk and Noni Juice

\begin{tabular}{lccccc}
\hline Code & $\begin{array}{c}\text { Water } \\
(\boldsymbol{\%})\end{array}$ & $\begin{array}{c}\text { ash } \\
(\boldsymbol{\%})\end{array}$ & fat & $\begin{array}{c}\text { protein } \\
(\boldsymbol{\%})\end{array}$ & $\begin{array}{c}\text { KH } \\
(\boldsymbol{\%})\end{array}$ \\
\hline P1 & 8,91 & 1,43 & 18,43 & 5,64 & 65,59 \\
\hline P4 & 6,09 & 3,28 & 18,34 & 5,44 & 66,85 \\
\hline
\end{tabular}

Based on table 6 above, it can be seen that the results of the nutritional content of kerupuk show that the ash content is more in $\mathrm{P} 4$, and the protein, fat and carbohydrate content differs slightly between P1 and P4.

\section{DISCUSSION}

Based on four different treatments of seluang fish kerupuk and noni juice:

1. $\mathrm{P} 1=100$ grams of Seluang fish +200 grams of tapioca flour +0 gram of Noni Juice

2. $\mathrm{P} 2=100$ grams of Seluang fish +200 grams of tapioca flour +50 grams of Noni Juice

3. $\mathrm{P} 3=100$ grams of Seluang fish +200 grams of 
tapioca flour +100 gram of Noni Juice

4. $\quad \mathrm{P} 4=100$ grams of Seluang fish +200 grams of tapioca flour +125 grams of Noni Juice

Based on four different treatments of Seluang fish Kerupuk and noni juice, namely P1, P2, P3 and P4, different Kerupuk were produced. Seluang fish Kerupuk and noni fruit juice produced in the P1 treatment are blacker in color, have a distinctive aroma of fish Kerupuk, and have a distinctive taste of fish Kerupuk and have the same texture as common of Kerupuk. In the P2 treatment, the resulting aroma is a little distinctive of seluang fish, the resulting color is brownish, the resulting taste tends to be like Kerupuk in general, the texture is crunchy like Kerupuk in general. In the P3 treatment the resulting aroma is not as thick as in P1 and P2, for the color is whiter than P1 and $\mathrm{P} 2$, and for the taste is more like a common Kerupuk, while the texture is crunchy. And for the last treatment, namely the $\mathrm{P} 4$ treatment, the resulting aroma is not too thick, for the color is whiter than P1, P2 and P3, and for the taste is more like Kerupuk in general, while the texture is crunchy.

\section{CONCLUSION}

From the results of the study, it was concluded that the best Kerupuk formula according to the assessment of the organoleptic test was Kerupuk P4 (200 grams of sago flour, 100 grams of fish, $125 \mathrm{ml}$ of noni juice). The results of the proximate analysis of $\mathrm{P} 4$ (water content $6.09 \%$; ash content $3.28 \%$; fat content $18.34 \%$; proteiN content $5.44 \%$; and carbohydrate content $66.85 \%)$.

\section{ACKNOWLEDGMENT}

The author is grateful to the Health Polytechnic of the Ministry of Health Palembang with DIPA funding and assistance Health Polytechnic of the Ministry of Health Palembang 2019 .

\section{REFERENCES}

[1] Sulistiyarto B. Hubungan Panjang Berat , Faktor Kondisi , dan Komposisi Makanan Ikan Saluang ( Rasbora argyrotaenia Blkr ) di Dataran Banjir Sungai Rungan, Kalimantan Tengah. J Ilmu Hewani Trop 2012;1:62-6.

[2] Rachmiaty R. Gambaran Asupan Sumber Kalsium dan FaktorFaktor yang Berhubungan pada Atlet Remaja Cabang Olahraga Renang di Klub Renang Wilayah Jakarta Selatan. Skripsi 2009.

[3] Rizalya Dewi RR. Factors Associated with Hypo Calcemia in Neo Natal Ward 2012;62.

[4] Baranowski T, Cullen KW, Nicklas T, Thompson D, Baranowski J. Are current health behavioral change models helpful in guiding prevention of weight gain efforts? Obes Res

[5] Brown JQ, Srivastava R, McShane MJ. Encapsulation of glucose oxidase and an oxygen- quenched fluorophore in polyelectrolytecoated calcium alginate microspheres as optical glucose sensor systems. Biosens Bioelectron 2005;21:212- 6. https://doi.org/10.1016/j.bios.2004.08.020.

[6] Bischoff JR, Anderson L, Zhu Y, Mossie K, Ng L, Souza B, et al. A homologue of Drosophila aurora kinase is oncogenic and amplified in human colorectal cancers. EMBO J 1998;17:3052 65.https://doi.org/10.1093/emboj/17.11.3052.

[7] Mason J. Qualitative Research 2002.

[8] Kesehatan K. Angka Kecukupan Gizi Yang Dianjurkan Untuk Masyarakat Indonesia 2006.

[9] Y Fenita. Pengaruh Pemberian Tepung Buah Mengkudu (Morinda Citrifolia L.) Dalam Ransum Terhadap Performansi Ayam Broiler. J Chem Inf Model 2012;53:1689-99.

[10] Duncan GJ, Brooks-Gunn J, Jean Yeung W, Smith JR. How much does childhood poverty affect the life chances of children? Am Sociol Rev 1998;63:406-23. https://doi.org/10.2307/2657556. 